\title{
LIST OF CHARACTERS
}

Characters are listed by ease of reference and so as not to spoil the plot

\section{The Oblonskys}

Stiva (Stepan Arkadyevich Oblonsky), Dolly's husband and Anna Karenina's brother

Dolly (Darya Alexandrovna Oblonskaya, née Shcherbatskaya), his wife The Oblonsky children include Tanya, Grisha, Lily, and Masha

Oblonsky Relatives

Princess Varvara, Stiva and Anna's aunt

Princess Katerina Pavlovna, her sister, the aunt who brought up Anna

Prince Peter Oblonsky, a dissolute relative and friend of Stiva's

Members of the Oblonsky Household

Matvei, Stiva's valet

Matryona Filimonovna, nurse to the Oblonsky children and Dolly's friend Princess Marya Borisovna, Kitty's godmother

\section{Stiva's Colleagues}

Mikhail Stanislavich Grinevich, Stiva's colleague at work

Filipp Ivanovich Nikitin, Stiva's colleague at work

Zakhar Nikitich, Stiva’s secretary

\section{The Shcherbatskys}

The old prince (Alexander Dmitrievich) and princess, parents of one son, dead as the novel begins, and of three daughters:

Dolly (Darya Alexandrovna), married to Stiva

Natalie (Natalya Alexandrovna), married to Arseny Lvov, a diplomat

Kitty (Katerina Alexandrovna), single as the novel begins

Nikolai Shcherbatsky, cousin to the Shcherbatsky sisters 
Friends and Associates of the Shcherbatskys

Mademoiselle Linon, former nurse to the Shcherbatskys

Countess Nordston, Kitty's married friend

Countess Bohl, a family friend

Madame Stahl, a philanthropic lady

Mademoiselle Varenka (Varvara Andreyevna), Madame Stahl's ward and Kitty's friend

Turovtsyn, friend of the Shcherbatskys and Oblonskys

Petrov, a patient

Anna Pavlovna Petrova, his wife

\section{The Karenins}

Alexei Alexandrovich Karenin, a high government official and Anna's husband Anna Arkadyevna Karenina (née Oblonskaya), Karenin's wife and Stiva's sister Seryozha (Sergei Alexeyevich Karenin), their son

Employed by the Karenins

Annushka, a longtime servant of Anna's

Kapitonich, servant of the Karenins

Kornei, butler

Mikhail Vasilyevich Slyudin, Karenin's secretary

Vasily Lukich, Seryozha's tutor

\section{Miscellaneous Associates of the Karenins}

Countess Lydia Ivanovna, a friend and philanthropic lady

Stremov, Karenin's political rival

Hannah, an English girl

\section{The Vronskys}

Count Alexei Kirillovich Vronsky, an officer

Count Alexander Kirillovich Vronsky, his brother

Varya, Alexander Vronsky's wife

Count Kirill Ivanovich Vronsky, Vronsky's father, long dead as the novel begins

Countess Vronskaya, Vronsky's mother, once notorious for her many affairs

Princess Betsy and Her Circle

Princess Betsy (Elizaveta Fyodorovna) Tverskaya, Vronsky's cousin

Tushkevich, Betsy's lover 
Princess Myahkaya, member of Betsy's circle

Liza Merkalova, member of Betsy's circle

Sappho Stolz, member of Betsy's circle

Vronsky's Friends and Acquaintances

Petritsky, officer and friend of Vronsky

Baroness Shilton, friend of Petritsky

Yashvin, Vronsky's friend, given to gambling

Prince Serpukhovskoi, a general and Vronsky's old friend

Golenishchev, Vronsky's old friend

\section{The Levins}

Kostya (Konstantin Dmitrievich Levin)

Nikolai Dmitrievich Levin, Levin's brother

Sergei Ivanovich Koznyshev, Levin's half-brother

Levin's sister, older than Levin

\section{Associates of the Levins}

Agafya Mikhailovna, Levin's former nurse, then his housekeeper

Kuzma, Levin's servant

Masha (Marya Nikolaevna), mistress of Nikolai Levin, former prostitute

Nikolai Ivanovich Sviyazhsky, Levin's friend, a liberal landowner

Stepan Vasilyevich, a conservative landowner

Fyodor Vasilyevich (or Mikhail Semyonovich) Katavasov, professor of natural science and Levin's friend

Chirikov, Moscow magistrate and Levin's friend

Mikhail Stepanovich Snetkov, nobleman and provincial marshal

Peter Ivanovich Metrov, a Petersburg scholar

Titus, a peasant on Levin's estate

\section{Miscellaneous Other Characters}

Mikhailov, a painter

Madame Mikhailova, his wife

Vasenka Veslovsky, a jovial fop

Nevedovsky, a provincial nobleman

Jules Landau (Count Bezzubov), a clairvoyant

Princess Sorokina, young friend of Vronsky's mother

Masha Chibikova, a dancer under Stiva's patronage 
xxxii List of Characters

\section{Children Born during the Novel}

Annie

Mitya

\section{Animals}

Krak, Stiva’s dog

Laska, Levin's dog

Pava, Levin's cow

Frou-Frou, Vronsky's horse

Gladiator, horse racing against Frou-Frou 